навчанні. Користуючись можливостями системи «Google», учитель і учні можуть відчути переваги різних видів оцінювання (само- i взаємооцінювання). Завдяки технології «Інтел» педагог може створити засоби оцінювання власноруч або використовувати напрацювання своїх колег. У такий спосіб учитель набуває ролі фасилітатора, консультанта, який спостерігає, спрямовує, підказує, керуючи навчальною діяльністю учнів за принципами гуманістичної педагогіки.

\title{
Література
}

1. Partnership for 21st Century Skills: [Електронний ресурс].- Режим доступу: www.21stcenturyskills.org 2. Зубченко О. С. Інформаційно-комунікаційні технології у педагогічній теорії та практиці Великобританії/ О.С. Зубченко // Сучасні інформаційні технології та інноваційні методики навчання у підготовці фахівців: методологія, досвід, проблеми: зб. наук. праць. - Київ-Вінниця : Планер, 2012.Вип. 33. - С. 19-23. 3. Коренькова Н. В. Способы оценивания учебной деятельности студентов / Н. В. Коренькова, А. Э. Кореньков // Оценивание: образовательные возможности: сб. науч.-метод. статей /под. общ ред. М. А. Гусаковского. - Мн. : БГУ, 2006. - Вып. 4. - С. 133-138. 4. Красильникова В. А. Теория и технологии компьютерного обучения и тестирования: [монография] / В. А. Красильникова. - М. : Дом педагогики, ИПК ГОУ ОГУ, 2009. - 339 с.

УДК $378.141: 64$

Олена Лихолат

\section{КОМПОНЕНТИ І ЧИННИКИ ФОРМУВАННЯ ЗМІСТУ НАВЧАЛЬНОГО КУРСУ «ДОМОЗНАВСТВО» В СИСТЕМІ ПІДГОТОВКИ ВЧИТЕЛЯ ТЕХНОЛОГІЙ}

Лихолат О. В. Компоненти і чинники формування змісту навчального курсу «Домознавство» в системі підготовки вчителя технологій.

У статті розкриваються теоретико-практичні аспекти формування змісту навчальної дисципліни «Домознавство» в системі підготовки вчителя технологій за спеціалізацією «Основи домашнього господарювання» Автор пропонує підходи до відбору складників змісту, обгрунтовує доцільність запровадження окремих навчальних модулів у змісті програми.

Ключові слова: технологічна освіта, зміст освіти, чинники, компоненти змісту освіти, принципи формування змісту освіти, навчальний курс «Домознавство».

Лихолат Е. В. Компоненты и факторы формирования содержания учебного курса «Домоводство» в системе подготовки учителя технологий.

Статья раскрывает теоретико-практические аспекты процесса формирования содержания учебной дисциплины «Домоводство» в системе подготовки учителя технологий по специализации «Основы домашнего хозяйствования». Автор предлагает подходы к отбору составных частей содержания, обосновывает целесообразность ввода отдельных учебных модулей в содержание программы.

Ключевые слова: технологическое образование, содержание образования, факторы, компоненты содержания образования, принципы формирования содержания образования, учебный курс «Домоводство».

Lykholat H. V. Components and factors of forming the content of the educational course "Housekeeping" in the system of training a teacher of technologies.

The article exposes theoretical and practical aspects of the process of forming the 
content of the educational discipline "Housekeeping" in the system of training a teacher of technologies in specialty "Fundamentals of housekeeping". The author offers approaches towards selecting components in the educational course and substantiates the reasonable introduction of separate educational modules into the content of the program.

Key words: technological education, content of education, factors, components of the content of education, principles of forming the content of education, an educational course «Housekeeping».

На всіх етапах розвитку суспільства зміст освіти зазнавав якісних змін під впливом різних чинників, таких, як соціально-економічні відносини, рівень розвитку виробництва, науки, техніки і культури, розвиту освіти та педагогічної думки, мети і завдань виховання, які ставить суспільство перед школою всіх рівнів акредитації. Гуманізація, як головна ідея сучасної освіти, сприяє поширенню особистісно зорієнтованого підходу до процесу формування змісту освіти, в тому числі і кожної навчальної дисципліни фахової підготовки вчителя технологій, спеціалізації «Основи домашнього господарювання». Кожна навчальна дисципліна обраної спеціалізації має бути пронизана ідеями гуманізму, любові до людини, родини, домівки, батьківщини і базуватись на нових досягненнях науки, техніки, технологій.

Практично весь час становлення та розвитку наукової педагогічної думки теоретики та практики розглядали проблему формування змісту освіти 3 різних позицій. В. Краєвський, І. Лернер [6, с. 137-161] свого часу розглядали зміст освіти 3 позицій практико-орієнтованого підходу, в основі якого лежить попередній досвід людства. І. Підласий [5, с. 316-332], А. Хуторський та інші науковці відзначають, що в процесі проектування змісту освіти особливу роль відіграють суперечності, що виникають в суспільстві, оскільки освіта $є$ підлеглою системою в ієрархії інших суспільно значущих систем.

Наукові дослідження змісту освіти у вищих навчальних закладах України свідчать про значні розбіжності в навчальних планах підготовки фахівців, програмах і засобах технічного забезпечення достатнього рівня практичної готовності випускників.

Саме тому заслуговує на спеціальну експлікацію зміст навчальної дисципліни «Домознавство» в системі підготовки вчителя технологій за спеціалізацією «Основи домашнього господарювання».

Meта статті полягає у визначенні головних компонентів та чинників, приципів та підходів формування змісту навчального предмета «Домознавство» в системі підготовки вчителя технологій за спеціалізацією «Основи домашнього господарювання» за освітньо-кваліфікаційним рівнем «Спеціаліст».

Проблема відбору змісту кожної навчальної дисципліни $є$ найважливішою проблемою педагогічної науки загалом [2; 3]. Вибір змісту, з одного боку, є завданням базових наук, а 3 іншого - визначається метою навчання, а також рівнем розвитку здібностей студентської молоді.

Навчальна дисципліна «Домознавство» належить до числа нормативних навчальних курсів ОКР «Спеціаліст» за спеціальністю 7.01010301 Технологічна освіта, спеціалізацією «Основи домашнього господарювання» і передбачає міждисциплінарний і системний підхід до вивчення основних проблем та технологій сучасного домашнього господарства в аспекті взаємодії людини, родини і суспільства 3 навколишнім середовищем.

Міждисциплінарний характер «Домознавства» зумовлений необхідністю вивчення умов збалансування економічних, культурних, екологічних, техніко- 
технологічних, здоров'язбережувальних, духовних та інших сфер життєдіяльності людини в сучасних домашніх умовах. Ця навчальна дисципліна має сприяти набуттю майбутніми вчителями технологій знань i вмінь щодо раціонального ведення домашнього господарства в умовах збалансованого природокористування з огляду на позитивні моменти емпіричного досвіду минулих поколінь та новітні досягнення науки, техніки та технології.

Навчальна дисципліна покликана формувати у студентів наукове розуміння взаємозв'язків основних понятійних категорій системи «Людина - Дім Середовище». Необхідно також формувати у студентів відповідальне ставлення до природи і іiі ресурсів, власного здоров'я та культурної спадщини нашої держави. Студент має бути готовим до активних дій з урахуванням принципів демократизації освіти, внутрішнього саморозвитку особистості, креативного стилю індивідуального життя людини, свободи педагогічної творчості, застосування сучасних технологій навчання та новітніх тенденцій викладання навчальних дисциплін.

Основними компонентами формування змісту навчальної дисципліни «Домознавство», на нашу думку, мають бути (за А. Кузьмінським) [1, с. 140-141]: когнітивний (пов'язаний з системою наукових знань про дім, домашнє господарство та сім'ю), який охоплює поняття, терміни, факти, закони, теорії та знання про способи дій; практичний (пов'язаний $з$ системою практичних умінь, навичок та способів діяльності у веденні домашнього господарства, організації житлового простору та сімейних відносин), який охоплює практичні, інтелектуальні, спеціальні та загальнонавчальні уміння; творчий (пов'язаний 3 досвідом творчої діяльності в домашньому господарстві), який охоплює вміння переносити вже набуті знання i вміння в нову ситуацію, бачення структури об'єкта і його нової функції, самостійне комбінування відомих способів діяльності в нові, знаходження різних способів розв'язання побутових проблем, побудову нового способу розв'язання проблем, що $\epsilon$ комбінацією відомих способів; комунікативний (пов'язаний з системою соціальних, мотиваційно-ціннісних та емоційно-вольових відносин в сім’ї та суспільстві), який охоплює оцінні знання, знання норм ставлення, уміння та навички дотримання норм поведінки.

При формуванні змісту навчальної дисципілни «Домознавство» ми зважали на такі аспекти: а) світоглядне значення предмета, що дає можливість зрозуміти закони суспільного та природного розвитку, здійснити аналіз усіх явищ і процесів, які відбуваються в сучасному домашньому господарстві, житловому просторі та сім’ї; б) пізнавальне значення предмета, його можливості щодо розвитку світогляду студента, надання цікавих, потрібних для майбутньої діяльності знань, стимулювання розвитку пізнавальної активності кожної особистості; в) суспільне значення предмета, його ролі в науковому, суспільному, культурному, економічному та духовному житті країни, соціуму; г) практичне значення предмета для кожного студента в контексті зв'язку $з$ обраною професією та можливістю оволодіння корисними практичними вміннями та знаннями за спеціалізацією; д) легкість засвоєння предмета, до якого студент виявляє інтерес; е) якість та рівень викладання навчальної дисципліни.

У процесі створення змісту навчальної програми «Домознавство» окрім інших ми додали ще $\mathrm{i}$ аксіологічний компонент. Студенти, в результаті вивчення дисципліни, повинні усвідомлювати необхідність зміни поведінки господаря в сучасному домашньому господарстві і неминучість переходу суспільства до нових реалій життя, вміти виявляти пріоритети в процесі організації та ведення домашнього господарства, обгрунтовувати рішення, пов'язані з розвитком соціально-економічних систем, як для прийняття управлінських рішень, так і для розробки сценаріїв розвитку 
житлового приміщення, родини, домашнього господарства загалом.

У процесі формування змісту навчальної дисципліни «Домознавство» ми застосовували, окрім «класичних», синергетичний принцип [4], що є характерним для складних (нелінійних) і динамічних систем, якими, на нашу думку, є домашнє господарство, житлове приміщення, сім'я. Вибраний нами принцип окреслює відкритість навчального процесу за спеціалізацією «Основи домашнього господарювання» до перманентних змін, до постійної науково-педагогічної творчості, до взаємодії майбутнього вчителя технологій з вчителями інших освітніх галузей, а також викладача і студента на паритетних, партнерських, а не авроритарних засадах. Цей принцип зумовлює розгляд базового поняття «Дім» (в триєдиному розумінні: житло, родина та господарство) як такого, що постійно саморозвивається в поліваріантному режимі завдяки внутрішнім суперечностям та їх постійному подоланні (за схемою: ... хаос - якісний стрибок - еволюційний відбір самоорганізація - порядок - розвиток - хаос ...). При цьому суперечності, які можуть виникнути у процесі існування системи «Людина- Дім- Середовище», розглядаються нами як позитивні чинники - імпульси для подальшого розвитку. Хаос ми розглядаємо у значенні нестійкості, невизначеності як позитивно діючого об'єктивного стану, який збуджує внутрішні енергетичні сили.

Ми також чітко розуміємо, що найбільше впливають на процес формування змісту освіти такі чинники [5, с. 317]: прийняття цілей, соціальні і наукові досягнення, соціальні потреби, особистісні потреби, педагогічні можливості.

У процесі аналізу наукових джерел змісту навчальної дисципліни «Домознавство» ми сформулювали певні загальні вимоги до відбору змістового складника:

Зміст навчальної програми повинен бути структурований відповідно до логіки побудови системи «Людина - Дім - Середовище» i передбачати всі аспекти функціонування сучасного домашнього господарства, родини та житлового простору. Слід відібрати з усієї навчальної інформації той обсяг матеріалу, який необхідний для передачі спеціалістам. Навчальний матеріал повинен включати теоретичну інформацію, сукупність практичних умінь і навичок, які необхідні для застосування цієї інформації, алгоритм дій щодо вирішення відповідних навчальних завдань та ситуацій.

Основою фахової підготовки спеціалістів за спеціалізацією «Основи домашнього господарства» повинні бути навчальні програми дисциплін спеціалізації загалом, так і зокрема навчального курсу «Домознавство», що однією 3 функціональних цілей мають забезпечити професійну підготовку майбутніх фахівців визначеної спеціалізації. У навчальній програмі варто реально визначити співвідношення аудиторної та самостійної роботи студентів, що передбачає чіткий розподіл навчального матеріалу між аудиторними заняттями та самостійною роботою. Окремо слід звернути увагу на процес вибору видів самостійної роботи, визначити реальні терміни їх виконання та критерії оцінювання. Конче необхідно також визначити форми поточного, періодичного та підсумкового контролю, плануючи заздалегідь завдання, форми їх реалізації та часові межі.

Теоретичні основи наукових галузей знань, що відображають сучасні досягнення у сфері домашнього господарства повинні реалізовуватись через систему професійної підготовки майбутніх спеціалістів. Слід пам'ятати, що зміст науки i зміст відповідного навчального матеріалу не $є$ тотожним, тому необхідно всю сукупність базових наукових знань проаналізувати не з точки зору абсолютної їх цінності, а відповідно до потреб конкретної спеціалізації. Варто також визначити реально 
можливі часові межі засвоєння інформації та всіляко сприяти ефективному поєднанню інформацій та теоретичних відомостей різних галузей науки, техніки та технологій, які так чи інакше пов'язані з домашнім господарством.

Формування змісту навчальної дисципліни повинно враховувати індивідуальні задатки і здібності, можливості та потреби студента щодо здійснення продуктивної навчально-пізнавальної діяльності. Слід адаптувати відібрану сукупність знань і практичних умінь до реальних можливостей студентської аудиторії, що визначається доступним рівнем складності засвоюваного навчального матеріалу, специфікою спеціалізації, метою та завданнями професійної підготовки вчителя технологій.

На технологічному факультеті державного вищого навчального закладу «Донбаський державний педагогічний університет» вивчення дисципліни «Домознавство» проводиться на першому курсі навчання студентів ОКР «Спеціаліст» спеціальності 7.01010301 Технологічна освіта, спеціалізації «Основи домашнього господарювання» в обсязі 5,0 кредитів.

Зміст дисципліни «Домознавство» розподілено на одинадцять логічно завершених змістових модулів (табл. 1).

Таблиия 1

Орієнтовна структура змісту навчальної дисципліни «Домознавство»

\begin{tabular}{|c|c|c|c|c|}
\hline \multirow{2}{*}{ Назва модуля } & \multicolumn{4}{|c|}{$\begin{array}{c}\text { Обсяг годин для окремих видів навчальних занять } \\
\text { і самостійної роботи }\end{array}$} \\
\hline & Лекції & $\begin{array}{l}\text { Лабора- } \\
\text { торні }\end{array}$ & $\begin{array}{c}\text { Самостійна } \\
\text { робота }\end{array}$ & Разом \\
\hline $\begin{array}{l}\text { 1. Організація домашнього } \\
\text { господарства }\end{array}$ & 5 & 12 & 8 & 25 \\
\hline $\begin{array}{l}\text { 2. Економіка родини та } \\
\text { домашнього господарства }\end{array}$ & 4 & 8 & 6 & 18 \\
\hline 3. Менеджмент домашніх справ & 4 & 8 & 6 & 18 \\
\hline $\begin{array}{ll}\text { 4. Сучасне житло. } & \text { Екологічні } \\
\text { основи організації } & \text { житлового } \\
\text { середовища } & \\
\end{array}$ & 4 & - & 5 & 9 \\
\hline 5. Ремонтні роботи в побуті & 4 & 4 & 6 & 14 \\
\hline 6. Побутова техніка & 4 & 8 & 6 & 18 \\
\hline 7. Заходи безпеки в побуті & 4 & 4 & 6 & 14 \\
\hline $\begin{array}{l}\text { 8. Кімнатні рослини, ми та } \\
\text { «брати наші менші» }\end{array}$ & 4 & 4 & 6 & 14 \\
\hline $\begin{array}{l}\text { 9. Краса та здоров'я. Секрети } \\
\text { здоров’я та довголіття }\end{array}$ & 4 & 6 & 5 & 15 \\
\hline $\begin{array}{l}\text { 10. Родинні зв'язки. Культура } \\
\text { поведінки та спілкування }\end{array}$ & 5 & 14 & 7 & 26 \\
\hline $\begin{array}{l}\text { 11. Юридично-правові основи } \\
\text { домоведення та сім’ї }\end{array}$ & 4 & - & 6 & 10 \\
\hline Усього годин & 46 & 68 & 66 & 180 \\
\hline
\end{tabular}

Працюючи над створення навчальної програми «Домознавство» ми розуміли, що неможливо створити єдино правильну й завершену концепцію навчальної дисципліни чи програму, бо будь-яка педагогічна система, в тому числі і система підготовки вчителя технологій за спеціалізацією «Основи домашнього господарювання» існує в постійному русі, у вічному устрімленні до ідеалу. Концепція програми та їі практичне 
впровадження - це не два послідовні етапи (теоретична аргументація ідей і практика, що є характерним для лінійного мислення), а дві сторони однієї медалі. Лише в постійному діалозі теоретичних ідей та практичної їх реалізації під дією чисельних змінних факторів, якими $є$ науковий поступ, економічні умови, соціокультурне середовище тощо, відбувається перманентне оновлення та корекція теоретичних положень навчальної програми.

Такий підхід відбиває загальнонауковий імовірнісний стиль мислення сучасності [7], який орієнтує на вивчення неоднозначних і принципово невизначених систем, що входять до поняття «Дім» в умовах багатофакторного опосередкованого детермінування навчальної дисципліни «Домознавство».

В авторській концепції навчальної програми «Домознавство» ми зробили спробу довести доцільність моделі поліцентричної інтеграції змісту, що передбачає включення одинадцяти різних змістових модулів, які об'єднані однією домінантою тривимірним поняттям «Дім».

Кінцевим результатом вивчення визначеної навчальної дисципліни має стати не лише сума знань, умінь та навичок (що цілком зрозуміло), а система цінностей та відповідна професійна компетентність.

Працюючи над навчальною програмою, ми передбачали цілісну педагогічну модель, що містить змістовий, функціонально-процесуальний i результативнооцінний компоненти навчання, виховання й розвитку особистості майбутнього вчителя технологій.

Розроблення змісту навчальних дисциплін, які б забезпечували формування у спеціалістів знань, умінь та навичок за обраним фахом, є одним із головних завдань вітчизняної школи. Грамотно сформований зміст навчальної дисципліни «Домознавство» повинен стати теоретико-практичною основою професійної компетентності майбутніх учителів технології за спеціалізацією «Основи домашнього господарства».

Формування змісту навчальної дисципліни «Домознавство» зумовлено такими чинниками: навчальним планом підготовки спеціалістів за спеціальністю 7.01010301 Технологічна освіта, спеціалізація «Основи домашнього господарювання» та змістовим наповненням навчальних тем «Домознавства» обов'язкових для вивчення.

\section{Література}

1. Кузьмінський А. I. Педагогіка : [підручник] / A. I. Кузьмінський, В. Л. Омеляненко. - [3-тє вид., випр.]. - К. : Знання - Прес, 2008. - 447 с. 2. Лсвшин М. Оновлення змісту багаторівневої професійно-педагогічної підготовки фахівців / Микола Лєвшин // Збірник наукових праць Переяслав-Хмельницького державного педагогічного університету ім. Григорія Сковороди. - 2007. - Вип. 22 23. - С. 24-30. 3. Леднев В. С. Содержание образования : сущность, структура, перспективы / В. С. Леднев. - М. : Высшая школа, 1991. - 224 с. 4. Малихін А. О. Синергетичний підхід до методичної підготовки майбутнього вчителя технологій / А. О. Малихін // Гуманізація навчально-виховного процесу. - 2011. - Вип. LVI. С. 131-138. 5. Подласый И. П. Педагогика. Новый курс : [учебник для студ. пед. вузов : в 2 кн.] / И. П. Подласий. - М. : Гуманит. изд. центр ВЛАДОС, 1999. - Кн. 1 : Общие основы. Процесс обучения. - 576 с. 6. Теоретические основы содержания общего среднего образования / под ред. В. В. Краевского, И. Л. Лернера. - М. : Педагогика, 1983. - 352 с. 7. Храмова В. Л. Целостность духовной культуры / Виктория Львовна Храмова . - [2-е изд.]. - К : Феникс, 2009. - 467 с. 